\title{
Characterization of bladder calculi and urinalysis in rabbits (Oryctolagus cuniculus) treated with mesenchymal adipose-derived stem cells (ADSCs) after partial urinary bladder allotransplantation
}

\author{
Caracterização de cálculos vesicais e urinálise em coelhos \\ (Oryctolagus cuniculus) submetidos a alotransplante parcial de \\ vesícula urinária e tratados com células-tronco mesenquimais \\ alogênicas derivadas do tecido adiposo (ADSCs)
}

\author{
Saulo Tadeu Lemos Pinto Filho ${ }^{1 *}$; Fabíola Dalmolin²; Renata Medina Pinho ${ }^{3}$; \\ Camila Feltrin Giglio ${ }^{4}$; Diandra Visentini Felin ${ }^{5}$; Kamila Lopes de Faria ${ }^{6}$; \\ Aline da Rosa Vargas ${ }^{7}$; Maurício Veloso Brun ${ }^{1}$; Marcos André Braz Vaz ${ }^{8}$; \\ Ney Luis Pippi ${ }^{1}$
}

\begin{abstract}
Bladder calculi associated or not with early crystalluria or salt deposits can be a common finding after reconstructive bladder surgery. The objective of this study was to characterize calculi and urine of domestic rabbits treated with mesenchymal adipose-derived stem cells (ADSCs) after partial urinary bladder allotransplantation. Twenty-four New Zealand White rabbits were submitted to surgery and treated postoperatively with cyclosporine or ADSCs for immunosuppression. There were no signs of graft rejection in either treatment group 30 days after surgery. Fewer animals presented bladder calculi in the ADSC treated group (33.3\%) compared to the cyclosporine treated group (58.3\%). Calcium was the predominant component of calculi in both groups. Urinalysis revealed no haematuria or bacteriuria in the ADSC group, in contrast to the results obtained for the cyclosporine group. ADSCs may be an attractive alternative to cyclosporine for immunosuppression after bladder allotransplantation.
\end{abstract}

Key words: Bladder. Surgery. MSC. Urolithiasis.

\section{Resumo}

A litíase vesical pode ser um achado comum quando se faz a reconstrução da bexiga, condição que pode estar associada a alterações precoces como cristalúria e presença de depósito de sais. O objetivo deste artigo é caracterizar os cálculos e a urinálise de coelhos domésticos submetidos a alotransplante de vesícula urinária e tratados com células-tronco alogênicas derivadas do tecido adiposo (ADSCs).

\footnotetext{
1 Profs. Universidade Federal de Santa Maria, UFSM, Santa Maria, RS, Brasil. E-mail: saulovet2011@hotmail.com; mauriciovelosobrun@hotmail.com;nlpippi@gmail.com

${ }^{2}$ Prof ${ }^{a}$, Universidade Federal da Fronteira Sul, UFFS, Realeza, PR, Brasil. E-mail: fabioladalmolinn@gmail.com

${ }^{3}$ Médica Veterinária Autônoma, Pelotas, RS, Brasil. E-mail: mpinho_renata@hotmail.com

${ }^{4}$ Médica Veterinária Autônoma, Porto Alegre, RS, Brasil. E-mail: camilafg.vet@gmail.com

5 Residente, UFSM, Santa Maria, RS, Brasil. E-mail: diandravf@hotmail.com

${ }^{6}$ Médica Veterinária Autônoma, Porto Velho, RO, Brasil. E-mail: kamilalopesdefaria@hotmail.com

7 Médica Veterinária Autônoma, Cachoeira do Sul, RS, Brasil. E-mail: alinevargas.vet@gmail.com

${ }^{8}$ Discente de Doutorado, UFSM, Santa Maria, RS, Brasil. E-mail: brazvaz@yahoo.com.br

* Author for correspondence
} 
Foram utilizados 25 coelhos Nova Zelândia Branco, os quais foram submetidos a alotransplante parcial de bexiga e tratados com ciclosporina (GCi) ou células-tronco mesenquimais (GCe) como agentes imunossupressores. Houve menor número de animais com cálculo vesical no grupo tratado com ADSCs (33.3\%), sendo cálcio o mineral mais frequentemente observado; na urinálise, os animais tratados com ADSCs não demonstraram hematúria e/ou bacteriúria. As ADSCs podem ser uma alternativa à ciclosporina para imunossupressão após alotransplante de bexiga.

Palavras-chave: Bexiga. Cirurgia. CTM. Urolitíase.

\section{Introduction}

Urine is a stable solution in which any variation in degree of saturation, $\mathrm{pH}$, or concentration of crystallization inhibitors can alter the equilibrium and cause urolithiasis in humans (TORRICELLI et al., 2013). In dogs and cats, urolithiasis is a common cause of lower urinary tract disease. Although the percentage of incidence in these species has not yet been established, it is believed that the range is between $0.2-3 \%$. Many minerals can precipitate in the urinary tract, with the most common being struvite (magnesium ammonium phosphate) and calcium oxalate (BARTGES; LANE, 2007).

The urine from rabbits differs from that of other species in that it normally contains many calcium carbonate crystals. Due to the unique calcium metabolism in this species, animals fed a diet rich in this element excrete a greater amount of calcium per volume of urine, which can result in the formation of 'bladder sludge', a paste-like suspension of small crystals. Subsequently, aggregation of crystals may occur and calculi may form, although the relationship between the formation of calculi and excess dietary calcium has not been established (LOPES, 2010). Diagnosed stones generally consist of calcium carbonate and other calcium salts and occur more frequently in domestic than in wild rabbits.

Piechota et al. (1998) used an acellular matrix as a bladder xenograft in rats in order to verify its reduced antigenicity. The authors prepared bladder acellular matrices from hamster, rabbit, and dog urinary bladders and grafted them to rats that had undergone partial cystectomy. In the control group, partial cystectomy only was performed. Bladder stones were found in $29 \%$ of the control group, with a mean of 1.1 stones/animal. In contrast, in grafted animals, $85 \%$ of animals presented stones, with a mean of 7.5 stones/animal. The most prevalent type of calculus was struvite, which was found in 60 to $100 \%$ of the stones from treated rats.

Oliveira et al. (2008) implanted a patch of bovine peritoneal membrane in rabbits as a substitute for a ventral fragment of the urinary bladder in order to evaluate the process of tissue repair. At each evaluation time point, macroscopic observation revealed the presence of bladder calculi consisting of calcium carbonate. The authors suggested that the implants induced formation of the bladder calculi.

Teixeira et al. (2007) performed allotransplantation in $\operatorname{dogs}$ to reconstruct the bladder after partial cystectomy, using cyclosporine as an immunosuppressive agent. The authors found no urinary calculi in animals observed for 60 days after surgery.

Cyclosporine, a cyclic peptide constituted by 11 amino acids, that is hydrophobic and is soluble in lipids and other organic solvents. These characteristics are responsible for its large volume of distribution and higher tissue concentrations. This drug has potent immunosuppressive activity and is unusual for its selective effect on lymphocytes. Its clinical use has revolutionized solid organ transplantation, significantly reducing morbidity and incidence of acute rejection. The most important collateral effect is acute or chronic nephrotoxicity (MENDES; BURDMANN, 2002).

Mesenchymal stem cells (MSC) are a population of somatic stem cells present in small amounts in perivascular regions of all adult tissues, including bone marrow, adipose tissue, periosteum, muscle 
tissue, and parenchymal organs. Cells isolated from adult tissues (mesenchymal, hematopoietic, and nervous) can give rise to various types of tissues such as pancreatic, hepatic, cardiac, and nervous. Initial evidence of the role of MSCs in the immune system showed that intravenous administration in baboons was able to prolong survival of allogeneic skin grafts, an effect similar to that of potent immunosuppressive drugs used in clinical routines. In addition to immunomodulation effects, MSCs express small amounts of major histocompatibility complex class I (MHC-I) molecules and little or no expression of MHC-II on their surface, causing these cells be well tolerated by the recipient organism (PINTO FILHO et al., 2013).

The objective of the present study was to characterize calculi and urine of domestic rabbits treated with mesenchymal adipose-derived stem cells (ADSCs) after partial urinary bladder allotransplantation.

\section{Material and Methods}

Twenty-four female and 1 male clinically healthy adult New Zealand White rabbits (Oryctolagus cuniculus) weighing $3.73 \pm 0.88 \mathrm{~kg}$ were obtained from the central animal facility of the institution where the study was conducted.

Animals were kept in individual cages in a standard laboratory environment for 15 days in order to adapt them to ambient conditions and handling and to detect any illnesses. During the study, animals received commercial food ${ }^{\mathrm{a}}$ and water ad libitum. Clinical examination and collection of blood samples for laboratory analysis were conducted (complete blood count, platelet count, BUN and creatinine levels, ALT, AST, ALP, and urinalysis). Blood was collected from the external jugular vein and urine was obtained by cystocentesis. All samples were immediately analysed in a clinical analysis laboratory in a controlled environment by technicians blind to the study.

After the observation period, the female animals were separated into two experimental groups (GCi and GCe), each with 12 animals, according to the type of post-transplantation treatment to be administered. Each group was subdivided into two subgroups of six animals each according to the length of the post-transplant evaluation period (either 15 or 30 days).

After the transplant procedure, GCi animals were treated with cyclosporine $\left(5 \mathrm{mg} \mathrm{kg}^{-1}\right.$ i.v.) every 24 hours until the end of the evaluation period (15 or 30 days). Animals in the GCe group received only one application of ADSCs $(0.8 \mathrm{~mL}$, containing $2 \times 10^{6}$ cells $\mathrm{mL}^{-1}$ ) that had been processed in the laboratory and cultured for three passages. The cells were applied intramurally and lateral to the grafting suture at the receiving bladder face. The purpose of both treatments was to prevent rejection of the urinary bladder allograft.

Adipose tissue collection, processing, and cell culture

A male rabbit was submitted to lipectomy, a surgical procedure to collect adipose tissue (AT) as a source of ADSCs. Pre-anaesthetic medication comprised a combination of ketamine hydrochloride (20 $\left.\mathrm{mg} \mathrm{kg}^{-1}\right)$, midazolam maleate (2 $\left.\mathrm{mg} \mathrm{kg}{ }^{-1}\right)$, and morphine sulphate $\left(5 \mathrm{mg} \mathrm{kg}^{-1}\right)$ applied intramuscularly (i.m.). Mask inhalation of isoflurane was used to promote induction and maintenance of anaesthesia. An AT fragment of approximately 10 grams was placed in a sterile glass container with $150 \mathrm{ml}$ of Hanks' solution and sent immediately to the cell laboratory. Inside a laminar flow hood, the AT was transferred to a Petri dish and divided into smaller fragments. The fragments were washed three times with Hanks' solution with the aid of a sieve that did not allow the passage of fat fragments. Fat was transferred to graduated polypropylene tubes $(50 \mathrm{~mL})$ and one-third volume of a of $1 \mathrm{mg}$ $\mathrm{mL}^{-1}$ collagenase type II solution was added. The tubes were capped and sealed with water-resistant film and put in a water bath at $37{ }^{\circ} \mathrm{C}$. Tubes were manually agitated every $5 \mathrm{~min}$ until the contents 
had a 'milky' appearance (approximately $25 \mathrm{~min}$ ). After being removed from the bath, the tubes were returned to the laminar flow hood and the collagenase was neutralized using an equal volume of complete Dulbecco's modified Eagle's medium (DMEM). The tubes were centrifuged at $600 \times g$ at ambient temperature for $5 \mathrm{~min}$ and then subjected to vigorous manual mixing in order to rupture the adipocytes and promote the release of mononuclear cells. Subsequently the tubes were returned to the centrifuge for $5 \mathrm{~min}$ at the same RCF.

The supernatant was discarded, and the remaining fraction was washed with complete medium and centrifuged at $440 \times g$ at room temperature for $5 \mathrm{~min}$. The washing and centrifuging process was repeated twice, after which the supernatant was discarded and the stromal vascular fraction resuspended in 1 $\mathrm{ml}$ of complete medium. A sample of this solution (70 $\mu \mathrm{l})$ was harvested using an automatic pipette and used for manual quantification of the percentage of mononuclear cells and a cellular viability test. The test was performed with 1\% Trypan blue using a Neubauer slide. Cells for primary culture were plated in $75-\mathrm{cm}^{2}$ bottles containing DMEM with $10 \%$ FBS. The bottles were placed in an oven at 37 ${ }^{\circ} \mathrm{C}$ and $5 \%$ carbon dioxide and allowed to expand for three passages, after which they were used in the GCe treatment.

Cells were characterized after the third passage by flow cytometry using anti-CD105, anti-CD90, anti-CD45, and anti-CD73, human antibodies, at dilutions recommended by the manufacturer, namely, 5:100, 5:100, 20:100, and 10:100, respectively. After 30 minutes of incubation with antibodies at room temperature, cells were washed with PBS and resuspended in $400 \mathrm{ml} \mathrm{PBS}$ for acquisition of data on a BD FACSDiva flow cytometer (BD Bioscience).

Anaesthetic and surgical procedure for partial urinary bladder transplantation

Prior to surgery, all animals were weighed and subjected to shaving of the abdomen as well as the ears to allow access to the auricular vein.

Pre-anaesthetic medication consisted of a combination of ketamine hydrochloride $\left(20 \mathrm{mg} \mathrm{kg}^{-}\right.$ $\left.{ }^{1}\right)$, midazolam maleate $\left(2 \mathrm{mg} \mathrm{kg}^{-1}\right)$, and morphine sulphate $\left(5 \mathrm{mg} \mathrm{kg}^{-1}\right)$ applied i.m. Anaesthesia was induced using isoflurane through a mask, with ampicillin (20 mg kg-1 i.v.) for antibiotic prophylaxis. Spontaneous breathing inhalational anaesthesia was maintained with isoflurane vaporized with $100 \%$ oxygen and applied through a mask, open inhale system, and spontaneous breathing. Ringer's lactate maintained venous access through cannulation of the caudal auricular vein with a $24 \mathrm{G}$ catheter, using a drip rate of 10 $\mathrm{mL} \mathrm{kg}^{-1} \mathrm{~h}^{-1}$.

For the transplant surgery, each rabbit was both donor and recipient. The procedures were carried out simultaneously in pairs in the same room. A pre-pubic scalpel incision through skin and subcutaneous tissue allowed access to the linea alba, which was incised using Metzenbaum scissors. After urinary bladder localization and exteriorization, cystocentesis was used to remove urine if present. After urinary bladder isolation with wet compresses using $0.9 \% \mathrm{NaCl}$ solution, three 3-0 nylon repairs were placed in the bladder apex. Subsequently an excision removed at most 30\% of the urinary bladder (measured empty), leaving the repairs on the remaining portion. The removed portion was washed with lactated Ringer's solution and immediately sutured to the remaining bladder of another animal. Suturing was carried out in a single plane using 5-0 polyglactin 910 sutures in a continuous pattern including serosa and muscular. When suturing was completed, bladder repletion with saline was used to check for possible leaks. Subsequently, ADSCs were applied as previously described. Suture of the linea alba was performed with 3-0 polyglactin 910 sutures in an isolated Sultan pattern; for the subcutaneous suture the surgeon used the same material and a simple continuous pattern. Skin closure was performed with 4-0 nylon and isolated points using Wollf standard. 


\section{Post operatory evaluation}

During the immediate postoperative period, animals received monitoring until complete restoration of consciousness and were then sent back to their individual cages. Rabbits received tramadol hydrochloride (6 mg kg-1 i.m.) every eight hours for three days as an analgesic. Cleaning of the wound was carried out with $0.9 \% \mathrm{NaCl}$ solution once every two days and skin sutures were removed seven days after surgery. During the observation time, a trained observer clinically evaluated the animals to identify any abnormalities related to the surgical procedure as well as to assess the presence of urine, urine volume, and its aspect. Clinical evaluation was performed daily from the day of surgery until the end of the predetermined evaluation period (15 or 30 days). Behavioural parameters of food and water ingestion were also observed.

At the end of the evaluation period, the animals were euthanized. After sedation with ketamine hydrochloride $\left(20 \mathrm{mg} \mathrm{kg}^{-1}\right)$, midazolam maleate (2 $\left.\mathrm{mg} \mathrm{kg}{ }^{-1}\right)$, and morphine sulphate $\left(5 \mathrm{mg} \mathrm{kg}^{-1}\right)$ i.m., animals received a further application of propofol (10 $\mathrm{mg} \mathrm{kg}^{-1}$ i.v.) applied in the auricular vein, according to CONCEA guidelines.

Necropsy was performed to collect material for histopathological analysis. In some animals, bladder calculi were present. Calculi were collected and chemically analysed in the institution's laboratory, using a commercial kidney calculus kit ${ }^{\mathrm{b}}$ and methodology based on a set of chemical and physical methods.

\section{Statistical analysis}

Microsoft Office Excel for Windows 7 was used to calculate means, and the paired t-test was used for statistical analysis. Values were considered significant when $\mathrm{p}<0.05$.

\section{Results and Discussion}

All animals tolerated the procedure and had satisfactory recovery. No behaviour changes or signs of graft rejection were observed during the postsurgical evaluation period or the final assessment. The animals were monitored daily for water and food intake and no changes in ingestion amount were noted. No signs of peritonitis, suture dehiscence, or rejection of the implant were observed in any subject, results similar to those reported by Oliveira et al. (2008). Teixeira et al. (2007) reported three deaths between 35 to 50 days after surgery, but the dogs in that study showed signs of implant rejection.

The rabbits in the GCi group received daily doses of cyclosporine, which can cause side effects, as an immunosuppressant agent during the entire observation period. According to Mendes and Burdmann (2002), the most important side effect is nephrotoxicity, which may present acutely or chronically. Acute presentation is characterised by reversible damage of renal function, with no significant renal histological changes. Clinically, asymptomatic elevation in serum creatinine occurs as well as delay in recovery of renal function after transplantation and, more rarely, haemolytic uremic syndrome. According to these authors and Diederich et al. (1994), this nephrotoxicity results from severe afferent arteriole vasoconstriction caused by cyclosporine, which generates hypertension and a decrease of renal blood flow. In our study, no animal treated with cyclosporine showed signs of nephrotoxicity. Creatinine values were maintained between $1.2-1.7 \mathrm{mg} \mathrm{dL}^{-1}$, within the normal range for this species $\left(0.5-2.5 \mathrm{mg} \mathrm{dL}^{-1}\right)$. Changes in serum urea were noted, with verified values between 33.4-69.2 $\mathrm{mg} \mathrm{dL}^{-1}$, which is considered high for the species (20-45 $\left.\mathrm{mg} \mathrm{dL}^{-1}\right)$. According to Melillo (2007), urea is a product of protein catabolism, and its level in rabbits can vary according to the quantity and quality of dietary proteins, nutritional status, hepatic function, intestinal absorption, and enzyme activity of cecal flora, among other factors. Thus, according to the author, small changes in urea levels are difficult to interpret, and a slight elevation of its blood urea level is a common finding in 
rabbits. The commercial food offered to the animals contained $17 \%$ crude protein, which, according to Couto (2002), is suitable for rabbit maintenance. Additionally, no animal showed signs of kidney disease during the experiment.

Vesical calculi were found in 58.3\% (7/12) of animals in the GCi group but in only $33.3 \%(4 / 12)$ of GCe group (Table 1). In both groups, calculi presented on the internal face of the implant (Figures 1A, 1B). Piechota et al. (1998), who grafted an acellular matrix originated from three different species into rats, also reported a higher percentage of bladder stones in transplanted animals (85\%) compared to the control group (29\%) that did not receive graft. According to Teixeira et al. (2007), who performed allotransplantation in dogs after partial cystectomy, urine changes such as crystalluria and salt deposits, as well as bladder calculi, are common soon after reconstructive surgery of the urinary bladder; however, in their study no such changes were observed 60 days after the transplant surgery. Oliveira et al. (2008) reported that implants led to the formation of calculi consisting of calcium carbonate but not of struvite, calcium oxalate, or calcium phosphate, all of which have been observed by other authors. Piechota et al. (1998), using rats, observed that the predominant mineral in calculi was struvite. In the present study, we observed the presence of a variety of constituents in the calculi, with calcium, phosphate, carbonate, and urate predominating (Table 1). Piechota et al. (1998), using rats, verified that the predominant kind of calculation was struvite. The main reason for this finding is that in mammals, $60-65 \%$ of the calcium in the glomerular filtrate is typically reabsorbed by the proximal tubule, and less than $2 \%$ of glomerular filtrate calcium is excreted in the urine. When the blood calcium concentration increases, glomerular filtration of calcium increases or absorption by the proximal tubule decreases, which leads to calciuria. In rabbits, the urinary excretion of calcium increases in parallel with the amount of dietary calcium. The percentage of calcium filtered by nephrons is higher in rabbits than in other mammals, and the percentage of excreted calcium in urine may reach 44.9\% (LOPES, 2010). As described above, Teixeira et al. (2007), working with another species (dogs), reported no formation of bladder stones in a study involving reconstruction of the urinary bladder via allotransplantation.

Figure 1. Presence of bladder stones in the urinary bladder of a rabbit (Animal 1, GCi group) that was treated with cyclosporine after partial urinary bladder allotransplantation (A). Bladder stone present on the mucosal portion of the implant (B).
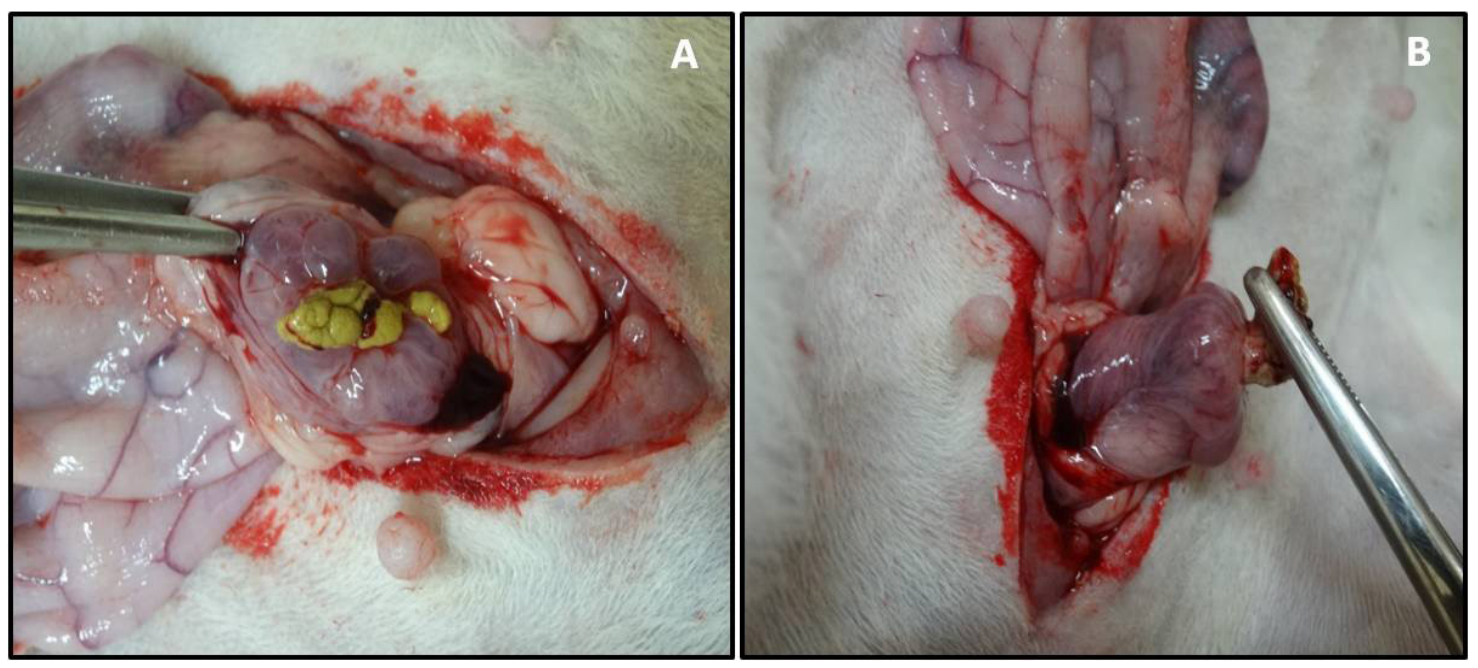
Table 1. Characterisation (composition) of bladder stones from rabbits that underwent partial urinary bladder allotransplantation.

\begin{tabular}{lccccccccc}
\hline Animals & Group & Carbonate & Oxalate & Phosphate & Calcium & Magnesium & Ammonium & Urate & Cystine \\
\hline C1 (15d) & GCi & + & - & + & + & - & - & $+*$ & $+*$ \\
C2 (15d) & GCi & + & - & + & + & - & - & $+*$ & $+*$ \\
C3 (15d) & GCi & + & - & + & + & - & - & + & - \\
C6 (15d) & GCi & - & - & + & + & - & - & + & - \\
C7 (30d) & GCi & - & - & + & + & + & + & + & - \\
C8 (30d) & GCi & + & - & + & + & - & - & + & + \\
C10 (30d) & GCi & - & - & + & + & - & - & $+*$ & - \\
C13 (15d) & GCe & + & - & + & + & - & - & - & - \\
C18 (30d) & GCe & + & - & + & + & - & - & + & - \\
C20 (30d) & GCe & + & - & + & + & + & + & + & - \\
C21 (30d) & GCe & + & - & + & + & - & - & + & - \\
\hline
\end{tabular}

* Small amount

Urine samples collected from both groups after transplantation appeared straw-yellow to darkyellow in colour and clear to turbid in appearance. In the GCi group, mean urine density 15 days postoperatively was $1035.60 \pm 9.63$ and $\mathrm{pH}$ was $6.60 \pm 1.08$, while animals evaluated 30 days after surgery urine density was $1030.00 \pm 2.45$ and $\mathrm{pH}$ was $6.30 \pm 0.84$. In the GCe group, urine density 15 days postoperatively was $1051.67 \pm 13.17$ and pH $7.92 \pm 1.36$, while 30 days after surgery urine density was $1054.60 \pm 6.31$ and $\mathrm{pH}$ was $8.40 \pm$ 1.34. Oliveira et al. (2008), who also used rabbits, reported a lower mean urinary density (1030) and variation in urine $\mathrm{pH}$ between 8.0 and 9.0; mean $\mathrm{pH}$ was not reported.

In the present study, three animals from the $\mathrm{GCi}$ group and nine from GCe group had urinary calculi. The presence of crystals in urine did not confirm the formation of calculi, and vice versa. Lopes (2010) confirmed the presence of crystals in urine from normal rabbits with no calculi. According to the author, the formation of calcium carbonate calculi in rabbits is usually attributed to an excess of these crystals in the urine, which in turn is caused by an excess of this element in the diet, although the relation between calculi and excess calcium in the diet is still not confirmed. The crystalluria observed in the GCi group was composed of calcium carbonate, consistent with findings of Oliveira et al. (2008). In the GCe group, calcium carbonate and triple phosphate were present, which could be explained by urinary alkalinisation in this group compared to the GCi group. Urinalysis data for the animals with bladder calculi are shown in Table 2. In contrast to the animals in the GCi group, animals in the GCe group with bladder calculi did not show erythrocytes or bacteria in the urine. 
Table 2. Urinalysis characteristics of rabbits that underwent partial urinary bladder allotransplantation and that developed bladder stones after surgery.

\begin{tabular}{lcccccccc}
\hline Animals & Group & Density & pH & Protein & $\begin{array}{c}\text { Occult } \\
\text { blood }\end{array}$ & Crystals & Erythrocytes & Bacteria \\
\hline C1 (15d) & GCi & 1048 & 7.5 & + & ++ & $\begin{array}{c}\text { Calcium } \\
\text { carbonate }\end{array}$ & - & Rare \\
C2 (15d) & GCi & 1028 & 7.0 & - & - & - & - & ++ \\
C3 (15d) & GCi & 1040 & 5.0 & - & ++ & - & $0-2$ & Rare \\
C6 (15d) & GCi & 1038 & 6.0 & Traces & ++ & - & 70 & Rare \\
C7 (30d) & GCi & 1028 & 7.0 & ++ & + & Calcium & $0-4$ & Rare \\
C8 (30d) & GCi & 1030 & 5.0 & Traces & - & - & - & Rare \\
C10 (30d) & GCi & 1030 & 6.5 & ++ & +++ & $\begin{array}{c}\text { Calcium } \\
\text { carbonate }\end{array}$ & $15-25$ & Rare \\
C13 (15d) & GCe & 1036 & 9.0 & Traces & + & - & - & - \\
C18 (30d) & GCe & 1045 & 9.0 & +++ & - & - & - & - \\
C20 (30d) & GCe & 1060 & 6.0 & +++ & ++ & $\begin{array}{c}\text { Calcium } \\
\text { carbonate }\end{array}$ & - & - \\
C21 (30d) & GCe & 1060 & 8.0 & + & - & $\begin{array}{c}\text { Struvite }(++) \\
\text { calcium }\end{array}$ & - & - \\
\hline
\end{tabular}

Two rabbits in the GCe group with bladder urolithiasis showed small amounts of occult blood in the urine, although without erythrocytes. According to Fighera et al. (2002), occult blood in cat urine may indicate methaemoglobinuria, haemoglobinuria, myoglobinuria, or haematuria. In the present study, no further testing was performed to identify haemoglobinuria or myoglobinuria, because animals showed no sign of any illness during the observation period. Ramirez et al. (2013) relate haemoglobinuria to copper poisoning in $\mathrm{New}$
Zealand rabbits; however, in the present study there was no sign compatible with any kind of poisoning, because the rabbits received only a balanced commercial diet intended for the species.

In this study, anti-CD105, anti-CD90, and antiCD73 antibodies were used for positive staining, while anti-CD45 antibody was used for negative staining, as recommended by Bydlowski et al. (2009). During cell culture cell attachment to plastic bottles and fibroblastoid morphology were observed (Figure 2). 
Figure 2. Cultivation of rabbit ADSCs in plastic bottles in a $5 \% \mathrm{CO}_{2}$ incubator (A). Fibroblastoid morphology of the cells during culture (B).
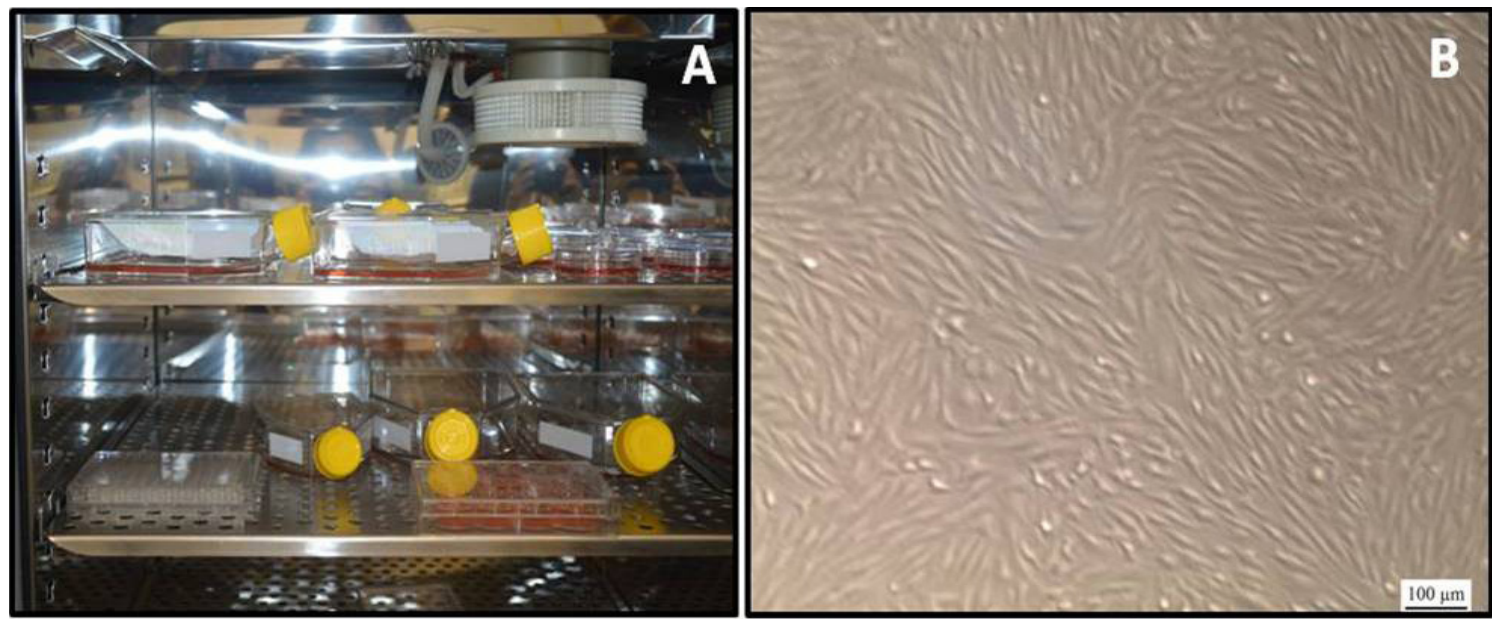

\section{Conclusion}

Fewer animals developed bladder stones in the ADSC treated group compared to the cyclosporine treated group. Calcium was the predominant component of calculi in both groups. Urinalysis showed no haematuria and/or bacteriuria in the ADSC group.

\section{Acknowledgments}

We thank Bioclin-Quibasa for donation of the urinary stone analysis kit (K008) used in this study. We thank Coordenadoria de Aperfeiçoamento de Pessoal de Nível Superior (CAPES) for a doctoral scholarship that allowed realisation of this and other research projects.

\section{Suppliers}

a - Supra Coelhos ${ }^{\circledR}$, Supra, São Leopoldo-RS.

b - Kit Cálculo Renal K008 ${ }^{\circledR}$, Bioclin-Quibasa, Belo Horizonte-MG.

\section{Ethics Committee}

The Comitê de Ética e Experimentação Animal of Universidade Federal de Santa Maria aproved

this project (number 066/2011) following ethical principles of Conselho Nacional de Controle de Experimentação Animal (CONCEA).

\section{References}

BARTGES, J. W.; LANE, I. F. Tratamento clínico da urolitíase. In: SLATTER, D. Manual de cirurgia de pequenos animais. 3. ed. São Paulo: Manole, 2007. Cap. 114, p. 1661-1672.

BYDLOWSKI, S. P.; DEBES, A. A.; MASELLI, L. M. F.; JANZ, F. L. Características biológicas das célulastronco mesenquimais. Revista Brasileira de Hematologia e Hemoterapia, Rio de Janeiro, v. 31, n. 1, p. 25-35, 2009.

COUTO, S. E. R. Criação e manejo de coelhos. In: ANDRADE, A.; PINTO, S. C.; OLIVEIRA, R. S. Animais de laboratório: criação e experimentação. Rio de Janeiro: FIOCRUZ, 2002. Cap. 12, p. 93-104.

DIEDERICH, D.; SKOPEC, J.; DIEDERICH, A.; DAI, F. X. Cyclosporine produces endothelial dysfunction by increased production of superoxide. Hypertension, Dallas, v. 23, p. 957-961, 1994.

FIGHERA, R. A.; SOUZA, T. M.; LANGOHR, I.; BARROS, C. S. L. Intoxicação experimental por cebola, Allium cepa (Liliaceae), em gatos. Pesquisa Veterinária Brasileira, Rio de Janeiro, v. 22, n. 2, p. 79-84, 2002.

LOPES, A. C. S. Cristálúria em coelhos. 2010. Monografia (Trabalho de Conclusão de Curso de Graduação em Medicina Veterinária) - Faculdade de Medicina Veterinária, Universidade Técnica de Lisboa, Lisboa. 
MELILLO, A. Rabbit clinical pathology. Journal of Exotic Pet Medicine, Philadelphia, v. 16, n. 3, p. 135145, 2007.

MENDES, G. E. F.; BURDMANN, E. A. Comparação da nefrotoxicidade experimental de duas formulações de microemulsão de ciclosporina A. Jornal Brasileiro de Nefrologia, São Paulo, v. 24, n. 1, p. 18-25, 2002.

OLIVEIRA, T. C.; SCAVONE, A. R. F.; MACHADO, M. R. F.; MAZZUCATTO, B. C. Cistoplastia experimental em coelhos (Oryctolagus cuniculus) com peritônio bovino conservado em glicerol a 98\%. Ciência Rural, Santa Maria, v. 38, n. 8, p. 2218-2224, 2008.

PIECHOTA, H. J.; DAHMS, S. E.; PROBST, M.; GLEASON, C. A.; NUNES, L. S.; DAHIYA, R.; LUE, T. F.; TANAGHO, E. A. Functional rat bladder regeneration through xenotransplantation of the bladder acellular matrix graft. British Journal of Urology, Malden, v. 81, n. 4, p. 548-559, 1998.
PINTO FILHO, S. T. L.; TREICHEL, T. L. E.; ARAMBURÚ JUNIOR, J. S.; ROSA, M. B.; DALMOLIN, F.; BRUN, M. V.; KRAUSE, A.; PIPPI, N. L. Células-tronco mesenquimais adultas: características e aplicações experimentais em animais. Veterinária $e$ Zootecnia, Botucatu, v. 20, p. 49-59, 2013.

RAMIREZ, C. J.; KIM, D. Y.; HANKS, B. C.; EVANS, T. J. Copper toxicosis in New Zealand White rabbits (Oryctolagus cuniculus). Veterinary Pathology, Liverpool, v. 50, n. 6, p. 1135-1138, 2013.

TEIXEIRA, M. W.; REZENDE, C. M. F.; SILVA JÚNIOR, V. A.; TEIXEIRA, M. J. D.; SILVA, E. C.; BARBOSA, D. G. Avaliação clínica e histopatológica de alo-transplante de bexiga em cães. Arquivo Brasileiro de Medicina Veterinária e Zootecnia, Belo Horizonte, v. 59, n. 2, p. 350-357, 2007.

TORRICELLI, F. C. M.; MAZZUCCHI, E.; DANILOVIC, A.; COELHO, D. F.; SROUGI, M. Tratamento cirúrgico da litíase vesical: revisão de literatura. Revista do Colégio Brasileiro de Cirurgiões, Rio de Janeiro, v. 40, n. 3, p. 227-233, 2013. 